\title{
Chapter 2 \\ Changing Lone Parenthood Patterns: New Challenges for Policy and Research
}

\author{
Marie-Thérèse Letablier and Karin Wall
}

Lone parenthood has become a widespread family living arrangement in the Western world. Not only has the number of lone-parent families been growing, but their profiles have changed substantially. Until the mid-1990s, lone parenthood was mainly the outcome of two trajectories: dissolution of a union due to the death of one parent, and childbirth out of wedlock. These two trajectories shaped at least two lone-parenthood patterns, which were viewed differently according to traditional social representations of family, filiation and parenthood. While widowed lone parents received compassion from society, unmarried mothers were stigmatized on account of their 'immoral behaviour'. Accordingly, their offspring were also perceived differently: compassion and solicitousness was accorded to orphans whereas shame awaited the children of unmarried mothers.

Today, in most European countries, lone parenthood results primarily from the dissolution of the matrimonial bond or the breakdown of a cohabiting relationship. This means that many children in lone-parent families have two parents but do not live full time with both of them under the same roof. Not only has change in lone parenting patterns modified the perception of these families but it has also contributed to the emergence of new questions for society. Policy objectives no longer focus solely on the replacement of the economic provider, generally the father, but extend to the maintenance of parental ties after the separation of the couple and on the risk of social exclusion for poor lone parents.

New patterns of lone parenthood present a number of challenges both for social policy and family research. First, lone parenthood has become more difficult to identify due to the greater diversity and complexity of living arrangements.

\footnotetext{
M.-T. Letablier ( $\square)$

Centre national de la recherche scientifique - CNRS - and Centre d'Economie de la

Sorbonne - CES - Université Paris1 Panthéon-Sorbonne, Paris, France

e-mail: marie-therese.letablier@univ-paris1.fr

K. Wall

Institute for Social Sciences, University of Lisbon, Lisbon, Portugal
} 
Secondly, lone parenthood is often a transitional step, since most lone parents are likely to repartner and reconstitute a family. The duration of lone parenthood varies according to sex, age and number of children. It should therefore be seen as a transitional period in the life cycle. While separated parents are likely to find a new partner and found a new family, children find a new place among an increasingly heterogeneous group of siblings, composed of children from different unions. Reconstituted families call into question traditional concepts of kinship and parenthood that are no longer restricted to biological ties. For a growing number of children, the term 'multi-parenthood' provides a more accurate representation of the diversity and complexity of family ties. Thirdly, lone-parent families deserve special attention in social policy because of their higher poverty risk.

In this chapter, we explore how lone parenthood challenges both family sociology and social policy in European countries, and more specifically in France, by focusing on three issues: first, the problem of defining lone parenthood, especially in view of the increasing complexity of family living arrangements; secondly, the prevalence of lone parent families and the relevance of a life-course perspective for capturing the changing patterns of lone parenthood; and, thirdly, the role of social policy in shaping lone parenthood.

\section{A Fuzzy Definition of Lone Parenthood}

Although there is a large body of research on lone parenthood, there have been relatively few cross-country comparative analyses of lone parent families. One reason is probably the lack of a common definition of lone parenthood for all countries in Europe, in addition to differences in national data sources. Another reason is the difficulty in reaching a precise definition of the concept. The definition that is usually used in the comparative literature tends to consider lone parent families as those "where a parent lives with his/her dependent children, without a spouse/partner, either on their own or in multi-unit households" (Duncan and Edwards 1997). This apparent simplicity in the definition conceals a number of problems that are amplified in cross-national comparisons. Three main issues may be mentioned: the age limit of children who are 'living with' the parent (under age 15, 16, 18 or 24); the criteria used to define a 'lone' living arrangement (which may include parents living on their own as well as those living with other adults in multi-unit households); and the meaning of being 'without a partner', in particular in a post-divorce/separation family arrangement. In the latter case, children may spend all their time with one parent but they may also spend time with the other parent or even alternate between two separate homes; moreover, the 'non-residential' parent may be involved in both the economic maintenance and the upbringing of his/her children, thereby contradicting the idea of a lone parent who is the only breadwinner and caregiver of his/her children.

Dependent children are not defined similarly in all countries and in all surveys. The age limit applied to children varies according to the data source and across countries depending on the norms for school-leaving age and the age of emancipa- 
tion from the family. In the European Labour Force Survey (ELFS), a lone-parent family includes at least one child below the age of 15, whereas in the European Community Household Panel (ECHP) a lone-parent family includes at least one child below the age of 16 or a child aged from 16 to 24 who is 'economically inactive', implying that s/he is economically dependent on his/her parent/s. In the European Panel Survey on Income and Living Conditions (EU-SILC), a lone-parent family includes at least one child below the age of 17 or an economically inactive child aged between 17 and 24. Similarly, in France, the age limit for children varies according to the data source. While data produced by the French Institut national de la statistique et des études économiques (INSEE) consider children or young adults under 25 who are economically dependent on their parents, the Caisse nationale d'allocations familiales (CNAF) usually refers to children under 20. Whereas INSEE gives preference to the 'residence' criterion (living with), CNAF emphasizes the 'budget unit' (household income and expenditure). The age criterion roughly reflects the degree of dependency, and therefore produces different assessments of the number of lone-parent families, even for the same year in the same country. The concept of dependent children is a social construction that depends on the purpose of the data collection as well as the institutional and cultural context. It partly reflects how children /young people are treated in the benefit system. Moreover, "dependence" covers financial dependence as well as dependence for care and other needs. So age matters, since childcare for instance is of little relevance for adult children.

Lone parents living in multi-unit households are particularly difficult to detect, especially when the household contains three generations. Moreover, they may or may not find parental substitutes and strong support in grandparents or other adults living in the same household, making it difficult to assess whether these are 'lone parent', 'multi-parent' or 'extended lone parent' families. The 'living alone' criterion is therefore controversial. Does it mean "living on one's own" and bringing up children without any economic or parenting support from other "breadwinners" or does it mean "living out of a stable partnership"? In most surveys it is understood as "not living with the other parent, nor with a new partner" though the "lone parent" may be living in a multi-unit household. In other words, the concept seems to draw specifically on the model of the 'nuclear family household' (cohabiting couple with children): lone parents are those who do not cohabit with a partner, whether or not they have support from other significant persons, be they non-residential partners, ex-partners or others.

Social and family policy institutions also adopt the 'living alone without a partner' criterion to exclude from support lone parents who are involved with a new partner even if the relationship is unstable. The criterion is based on a subjective statement by an individual, which is particularly problematic for lone parents in French overseas territories where lone parenthood is a widespread social phenomenon $^{1}$ and where the relationships between all household members are not clearly

\footnotetext{
${ }^{1}$ In Martinique, $53 \%$ of households with dependent children are lone-parent households, and six out of ten teenagers live partly or wholly with one parent for the first 15 years of life.
} 
captured in surveys. In the French Caribbean territories where one-parent families are twice as numerous as in continental France, the lone parent is almost always the mother but in most cases fathers do not completely disappear. In 2004, approximately $70 \%$ of childbirths were out of wedlock in Martinique, often involving 'multi-partnership' for fathers (Lefaucheur and Brown 2011). Anthropologists have shown that the extension of these family forms reveals the centrality of the maternal figure, while the father's role is blurred (Mulot 2013). This example shows that, in some societies, lone motherhood is embedded in cultural and social gender conventions. The traditional nuclear family composed of a parental couple and children throughout life, hitherto considered as the reference norm in European countries, is no longer relevant for the variety of family life arrangements in a global context of growing cultural diversity.

Lastly, the concept of lone parenthood is not always appropriate because a growing number of children who live in lone-parent families have two parents. In the 1970s, at least in France, the issue in public debate was how to legitimate lone parents as families while avoiding the stigmatization of unmarried mothers (Lefaucheur 1986). In the twenty-first century, the issue is how to identify families in which children do not live with their two parents, in the knowledge that many children living mainly with one parent have a more or less regular relationship with the nonresidential parent who contributes to their maintenance and upbringing. The concept is made more complex by the need to distinguish lone-parent families in which children never see the non-residential parent (a "lone" lone-parent family) from those where children regularly stay with the non-residential parent and/or share their time and residence between the two parents (a lone "bi-parental" family). In this case, the child can be said to live in two households with two parents who share maintenance, care, education and love. From a sociological perspective, it is essential to identify and conceptualize these situations as different. Moreover, the development of shared residence and shared parenting in some countries raises the problem of the double counting of lone-parent families. This is a crucial issue for household surveys to deal with (Toulemon and Pennec 2010).

Research on families in other societies also points to the need to reflect more carefully on the appropriateness of the concept of lone parenthood. Authors of a survey of conjugal violence against women in Martinique distinguish three patterns of lone motherhood: lone mothers (23\%) who have never been married or cohabited with a partner (more than $25 \%$ had always lived with their parents, even when aged over 40 ); lone mothers (35\%) who have a regular relationship with the child's father who is partnered with another woman; and separated mothers (42\%) whose children were born before the separation (Lefaucheur and Brown 2011). The term 'friends' was suggested by demographers in the beginning of the 1970s to identify the second type of lone mothers who have more or less regular sexual relationships with a partner with whom they are neither married nor cohabiting (Leridon et al. 1970). Anthropologists refer to this situation as a 'visiting union' in which fathers are 'visiting fathers' (Mulot 2013). 
These examples suggest that lone parenthood takes place in a context of 'inconstance de la famille' ('changeable and plural family forms') ${ }^{2}$ (Leridon and VilleneuveGokalp 1994), and that lone-parent living arrangements are diverse and complex, hitherto difficult to capture. They also reveal that current definitions of lone parenthood are embedded in cultural norms emphasizing the concept of the nuclear family household based on the ideal of a cohabiting parental dyad. There has been little effort to unpack the concept itself and to grasp the diverse sociological meanings of a 'non-cohabiting mother/father living with dependent children'. These problems and gaps would call for more research as well as new theoretical frame. For example, to move beyond the nuclear household concept, it would be useful to adopt network and configurational approaches to lone parenthood, in order to take into account family bonds and meanings that bridge across different generations, couples and households, as several authors suggest (Widmer 2010; Wall and Gouveia 2014). A life course perspective, bringing in the principle of linked or interdependent lives, would also provide a more dynamic and complex view of lone parenthood.

\section{Variation and Change in the Prevalence of Lone Parenthood}

The increase in divorce and separation involving children has led to an increase in lone parenthood over the last decades. The OECD Family database provides data on children's living arrangements, providing a comparative overview of the incidence of lone parenthood in Europe (Table 2.1).

The proportion of children below age 18 living with one parent varies extensively from $5.3 \%$ in Greece, $7.2 \%$ in Spain, $10.2 \%$ in Italy for the lowest rates to $24.3 \%$ in Ireland, $21.5 \%$ in the UK, 21.8\% in Estonia for the highest rates in Europe. With $13.5 \%$ of children living with one parent, France stands in between, close to Austria, Finland, and Germany (Table 2.1). The lowest shares are found in Southern European countries whereas the highest are found in Nordic countries and above all in the UK and Ireland. With the exception of Estonia, the central and eastern European countries show close to average values, higher in Hungary and the Czech Republic than in Poland, Slovak Republic and Slovenia.

Although the OECD does not provide data on different types of "one parent families", it informs on the share of children who live with two married parents (Table 2.1). Again, the proportion is far higher in Southern European countries than in the Nordic countries or in the UK. The highest shares are found in Greece, Italy, Spain, while the lowest are found in Sweden and Estonia. Moreover, the proportion of children living in multigenerational households varies from less than $1 \%$ in Sweden, the Netherlands, Denmark, Finland and Germany, to more than $10 \%$ in Hungary, Portugal, and Estonia. The highest rate is found in Poland, where 22\% of

\footnotetext{
${ }^{2}$ This play on words refers to the "inconstance" (inconstancy) in love relationships and applies it to change in family living arrangements. It also refers to instability of the couple over the life course.
} 
Table 2.1 Distribution of children by household type in selected EU countries, 2007

\begin{tabular}{|c|c|c|c|c|c|c|}
\hline & \multicolumn{4}{|c|}{$\%$ of children cohabiting with $\ldots$} & \multirow[b]{2}{*}{ Total } & \multirow{2}{*}{$\begin{array}{l}\% \text { of children in } \\
\text { multi-generational } \\
\text { households }\end{array}$} \\
\hline & 0 parent & 1 parent & $\begin{array}{l}2 \text { cohabiting } \\
\text { parents }\end{array}$ & $\begin{array}{l}2 \text { married } \\
\text { parents }\end{array}$ & & \\
\hline Austria & 2.2 & 14.3 & 7.4 & 76.1 & 100 & 7.5 \\
\hline Belgium & 2.5 & 16.2 & 13.7 & 67.7 & 100 & 2.2 \\
\hline Czech Rep & 0.6 & 14.9 & 8.2 & 76.3 & 100 & 7.7 \\
\hline Denmark & 1.5 & 17.9 & 15.1 & 65.6 & 100 & 0.4 \\
\hline Estonia & 1.9 & 21.8 & 23.9 & 52.5 & 100 & 12.0 \\
\hline Finland & 0.9 & 14.4 & 15.8 & 68.9 & 100 & 0.6 \\
\hline France & 0.9 & 13.5 & 21.0 & 64.5 & 100 & 1.8 \\
\hline Germany & 1.3 & 15.0 & 5.5 & 78.2 & 100 & 0.9 \\
\hline Greece & 1.2 & 5.3 & 1.2 & 92.3 & 100 & 6.5 \\
\hline Hungary & 0.8 & 15.4 & 9.9 & 73.9 & 100 & 11.6 \\
\hline Ireland & 1.9 & 24.3 & 5.9 & 67.9 & 100 & 4.5 \\
\hline Italy & 0.8 & 10.2 & 5.2 & 83.9 & 100 & 5.0 \\
\hline Netherlands & 0.3 & 11.1 & 13.1 & 75.5 & 100 & 0.3 \\
\hline Portugal & 2.9 & 11.9 & 9.7 & 75.5 & 100 & 11.6 \\
\hline Poland & 0.8 & 11.0 & 9.2 & 79.0 & 100 & 22.0 \\
\hline Spain & 1.2 & 7.2 & 7.9 & 83.7 & 100 & 5.8 \\
\hline Sweden & 1.3 & 17.6 & 30.5 & 50.6 & 100 & 0.3 \\
\hline UK & 1.4 & 21.5 & 12.6 & 64.5 & 100 & 3.4 \\
\hline
\end{tabular}

Notes: 1- The category "cohabiting parents" includes unmarried parents and parents in reconstituted households. 2- Children are defined as household members under 18

Source: OECD, Doing better for families, 2011 (OECD family data base)

children below the age of 18 live in such households. Data do not however specify whether these households include the two parents of the child or one only, or even no parents. These figures reflect the contrasted incidence of intergenerational coresidence and support, which tends to be stronger in Central, Eastern and Southern European countries than in Scandinavia, where individual and residential autonomy is less of a problem.

The prevalence of lone parent families must therefore be examined in the wider context of the increasing diversity and complexity of family living arrangements, norms and practices. It should also be examined in a life course perspective given the changing family forms over the life course due to breaks and discontinuities in couples' life. The lowest rate of lone parenthood seems to be correlated with the high incidence of marriage and subsequently with the lower incidence of unmarried partnership as observed in Greece, Spain and Italy (Table 2.1). It reflects a family pattern in which marriage remains the norm for couple's living arrangements, unmarried cohabitation is low, divorce is not yet widespread and intergenerational family solidarity is more common. This pattern contrasts with a family pattern characterized by more fluidity and diversity of family forms, a relatively high proportion of unmarried parents, a high rate of divorce and a high proportion of children living either with one parent for most of the time, or in a reconstituted family, 
or alternately with each of the parents. This pattern in which very few children live in multi-generational households is commonly widespread in Nordic countries. In between are different sub-patterns combining a low or medium rate of children living with a lone parent with various shares of children living with two cohabiting parents or in reconstituted families.

In summary, a significant number of children now live most or all of the time with one of their parents, and the increase in the proportion of divorces involving children has been accompanied by a rise in lone parenthood over the past few decades (Chapple 2009; Chzhen and Bradshaw 2012) Across the OECD countries, one child in eight (15\%) lives with one parent only, while nearly $84 \%$ of children live with two married or cohabiting parents. Moreover, projections to 2025-2030 suggest that numbers are likely to increase in many countries, even if the effect of a rise in divorce and separation is unlikely to substantially mitigate that of declining numbers of children (OECD 2011). Beyond this general trend, the changing diversity and complexity of lone parent families has to be examined in the context of multiple shaping factors such as changing gender and parental roles, marital status, trends to repartner, number and age of children, and lone parents' employment and living conditions. As mentioned above, it is also crucial to introduce a life course perspective in order to understand the duration and incidence of lone parenthood across different life stages.

Much comparative cross-national data is missing on these issues, and it is mainly national data sets that allow us to highlight and fully understand the main trends related to the new plurality and complexity of contemporary forms of lone parenthood, in particular in a life course perspective. We will therefore begin by analyzing the French case before looking again at lone parenthood patterns in comparative perspective.

\section{Changing Reasons and Trajectories of Lone Parenthood in France}

Until the 1970s, lone parenthood in France resulted predominantly from the death of one of the parents and/or from single ${ }^{3}$ motherhood. Today, lone parenthood results mainly from divorce or separation of a cohabiting couple. More than $62 \%$ of lone parents were previously married or cohabiting while $20 \%$ never lived in a couple and $18 \%$ became lone parents after the death of a spouse or partner (Letablier 2011a).

Lone parenthood due to the death of one parent is therefore much less likely to be the reason for 'living alone with children' in France. The proportion of widows among lone parents fell from 55\% in the early 1960s to under 10\% in the mid-2000s (Chardon et al. 2008). However, the high incidence of accidents at work among

\footnotetext{
${ }^{3}$ The term 'single' is used here in the sense of never married or partnered, by contrast to 'lone' that refers to living without the father or a new partner.
} 
manual workers explains the larger number of orphans among children of blue collar workers: $9.8 \%$ compared to $5.1 \%$ for children of professional workers. On average, widowed lone parents are older and better off than other lone parents. The majority are mothers, with children on average older than in other lone-parent families. Lone parenthood due to the death of one of the parents is however more often temporary than for other forms of lone parenting. A French survey of family histories carried out since the 1990s by the Institut national d'études démographiques (INED) shows that $50 \%$ of widowed lone parents were partnered again 4 or 5 years after the death of the partner, whereas $25 \%$ were still living alone 19 years later, mostly women with several children. The survey also shows that widowers were more likely to repartner than widows, all the more so if they are women with several children (Lefèvre and Fillon 2005).

Single mothers who never married or cohabited before childbirth display a second profile of lone parenthood, which varies according to different life trajectories. Some result from the choice of having a child with a married man for instance, or the mother's decision to adopt or get pregnant and bring up a child by herself, while others result from an unwanted pregnancy which was further accepted. Although it is difficult to assess the number of single mothers who have not lived with a partner before childbirth or the number of separations during pregnancy, INED estimates at between 5\% and 7\% per year the proportion of such births in France. The proportion of unpartnered or unmarried mothers accounts for around $15 \%$ of all lone parents, including $13 \%$ of mothers without any form of cohabitation and $2 \%$ of couples that have separated before birth (Haut Conseil de la Famille - HCF 2010). These never partnered mothers are generally younger than lone mothers in general. They also have a lower level of education, but in contrast to the UK and Ireland where early pregnancies are more widespread, they are rather exceptional in France.

A third profile refers to couples who have separated or divorced. This life-course trajectory now represents the most widespread reason for lone parenthood in most European countries. It is however uneasy to distinguish lone parenthood resulting from the separation of a never-married couple from that due to the divorce of a married couple. Estimates for France suggest that half of relationship breakdowns are due to divorce and half to separations of never-married couples. Divorce occurs on average after 14 years of marriage, at the age of 40 for women and 43 for men. Altogether $56 \%$ of divorces involve at least one dependent child. Re-partnering after divorce or separation occurs more or less rapidly according to parental status, custody arrangements and number and age of children. On average, half of divorced parents re-partner within 5 years after divorce, compared to half of separated parents who re-partner within 3 years after separation. Divorced parents are on average older than separated parents, and their children are also older: eight and a half compared to four and a half. With regard to the level of education and qualifications, divorced or separated mothers do not differ from partnered mothers. They have a higher level of education and higher labour force participation than never partnered lone mothers.

Post-divorce and post-separation custody arrangements are also important to understand the transitions into and out of lone parenthood. According to tax declarations, 1 year after the divorce of the parents, $76 \%$ of dependent children in France 
live most of the time with the mother, only $9 \%$ with the father and $15 \%$ alternately with mothers and fathers (Bonnet et al. 2015). This is different from Sweden, where only $65 \%$ of dependent children with separated parents live most of the time with their mother, $17 \%$ with their father, and $18 \%$ share their time equally between the two parents (Hobson et al. 2011). In contrast, in the UK the vast majority of children live with their mother (Finn 2011). These figures reflect the social acceptability of lone parenthood as well as the changing perceptions of gender roles and parental responsibilities. For example, whereas the focus in Sweden is on children and their living arrangements according to a child-centred perspective, more attention has been paid to lone mothers in the UK (mother-centred approach), while the focus was for a long time on families (family-centred) in France (Letablier 2011b). Whatever the approach, living arrangements for children are increasingly complex and uneasy to capture, depending mainly on the amount of time they spend respectively in the mother's or father's home, as well as on each parent's economic contribution to the child maintenance, education and care. In addition, as mentioned above, these living arrangements may change over time since the lone parent may find a new partner and children may want to change their place of residence as they grow up.

The social and ethnic status is another variable that shapes transitions to parenthood and lone parenthood. The number of lone parents has grown more rapidly among immigrants than among the native French population. Their number more than doubled over the last two decades, from 143,000 in 1990 to 298,000 in 2008 (Mainguené 2013). On average, 6\% of immigrants aged 18 and over are lone parents compared to $4 \%$ of non-immigrants. The increase is concomitant with the changing migration regime. The "new" regime differs from the previous one regarding origin, gender, and objectives. Each of these features may affect lone parenthood growth among migrants. First, with respect to regional origin, although the share of lone parents is roughly similar to the average for immigrants from Europe, Morocco, Tunisia or Turkey, it is notably higher for immigrants from other African regions. The proportion of lone parents among the "new migrants" from subSaharan Africa and Asia is as high as 12\% (Insee 2012). One explanation could be the social and family structures in the country of origin. In the Sahel, men, women and children generally live separately in different places of residence. This contrasts with the Western conception of the family as a unit composed of a married/partnered couple living with their children in the same home. The second change in the migration regime results from the growing number of women among the new migrants. Thirdly, women are now not only more numerous than men among migrants but they also do not always come to join a husband or a partner but instead have their own autonomous life project. Nowadays, the main reason for coming to France is to study or to work (Beauchemin et al. 2013). Most of these new female migrants come from the Ivory Coast, Cameroun or the Democratic Republic of Congo. Some of them are not married while others have left their husbands in the country of origin. These 'living apart together families' or "distance families" subjectively feel they are lone parents. The more rapid growth of lone parents among immigrant families than among the French native population suggests that changes 
in the migratory regime and the experience of lone parenthood might be linked. So far, the issue has not been fully explored.

Changes in the reasons for lone parenthood, together with the decline in female adult mortality and the fact that, after divorce or separation, the vast majority of children live mainly with their mother, explain the low proportion of lone fathers among lone parents. The share of lone fathers in France fell from 20\% in 1970 to $14 \%$ in 1990, then rose to $15 \%$ in 2005 (Chardon et al. 2008). The rebound in the mid-2000s reflects the emergence of a new lone parenthood pattern in which fathers are more involved in parental responsibilities and duties than they were previously. As mentioned above, this also results from a (slow) change in custodial arrangements since alternating custody now concerns $15 \%$ of children 1 year after the divorce of their parents (Bonnet et al. 2015). It also reflects a change in men's aspirations to share parental responsibilities, as well as policy incentives to achieve gender equality in family life. The French law of 1970 on joint parental responsibility legally and symbolically closed the era of the Pater familias as the economic provider for the family and main source of authority. Then the law on joint parental responsibility in 2002 set forth the principle of co-parenting according to which parental responsibilities should be equally shared between the parents, whatever their living arrangements. Concomitantly, societal expectations regarding fatherhood gradually changed. Fathers of today are expected to share the responsibility for childrearing with mothers, and to be increasingly involved in their children's lives, whatever their living arrangements with the mother. While mothers' participation in the labour force has been continuously increasing over the past 50 years, reconciliation of work and family life has become an issue for both mothers and fathers. After divorce, an increasing number of fathers apply for shared custody, making lone fathers an issue of growing interest for research (Martial 2013a, b). The relationship with the non-residential parent is found to depend on the father's involvement in childcare before separation. Fathers who had been sharing parental responsibilities before splitting up often claim equal sharing after separation. The success of co-parenting also depends on the quality of divorce measured in terms of the level of conflict before and during the procedure (Martial 2013c).

\section{Lone Parenthood in France as a Transition in the Family Life Course}

Surveys usually capture living arrangements at a particular point in time, thereby providing a snapshot of lone parenthood, rather than tracking changes over the life course. Given the change in lone parenthood patterns, with divorce and separation frequently followed by re-partnering and family reconstitution, it is ever more relevant to conceptualize and analyze lone parenthood as a stage in the life course. Today, in France, 11\% of children live in a reconstituted family with brothers and sisters from a previous union. Reconstituted families account for almost $8 \%$ of 
families with at least one child under 18. One marriage in five is a remarriage, and 93\% of remarriages occur after a divorce while $7 \%$ occur after the death of one of the parents.

Repartnering after the dissolution of a marriage or after separation of a cohabiting couple depends on factors which not only weigh on the likelihood of the repartnering process but also on its tempo. The presence of children from a prior union and the custody arrangements affects the repartnering process (Vanassche et al. 2015). Interestingly, a study based on survey data in Flanders shows that compared with other divorcees, full time residential parents are the least likely to start a new union following a separation, and that parents are more likely to start a union with another parent than with a childless partner. Evidence from this study suggests that parenthood may not be a particularly attractive status for post-separation union formation. However, results from French surveys show that parental status has a different incidence for men and women, as well as the living arrangements prior to lone parenthood. After a divorce, fathers who have custody of their children reconstitute a family more rapidly than fathers without custody: more than one in two fathers with custody are re-partnered 4 years after the union breakdown, compared to $39 \%$ of fathers without custody. The reverse applies to women, but the gap is smaller than for fathers. Women re-partner more rapidly when they do not have custody: one third of mothers without custody will again be living in a couple 4 years after the breakdown, compared to $27 \%$ of those who have custody These figures suggest that the custody arrangements strongly influence the process of repartnering. They also suggest that the effects of the child "burden" on new relationships differ for men and women.

Whereas the duration of lone parenthood is on average 5.5 years, the duration is lower for separated parents (4.5 years on average) or widowed (5.5 years) and higher for never partnered parents (10 years). The duration is also longer for lone mothers than for lone fathers, respectively 5.6 years and 4.2 years on average, but the gap is partly due to the fact that one lone mother in six has never been partnered whereas this situation is rare for lone fathers. Duration of lone parenthood is also longer for low educated parents than for other lone parents: $24 \%$ of lone mothers and $15 \%$ of lone fathers with a low level of education have been lone parents for more than 10 years compared to $14 \%$ of lone mothers and $7 \%$ of lone fathers with a university degree (Buisson et al. 2015). Therefore, men are more likely than women to reconstitute a family and to do so more quickly. Reconstituting a family is three times more common for widowed men than for widowed women aged below 55: about half of widowed men below 55 re-partnered after the death of their wife, compared with only $17 \%$ of widowed women, from 1990 onwards (Lefèvre and Filhon 2005).

Repartnering and childbearing produce increasingly complex family patterns. The concept of 'pluri-parentality' is used to capture the various relationships between children and their biological or social parents (Théry 2013). For instance, the biological father may not be the parent who looks after the child in everyday life, and the child may have closer bonds with the stepfather than with the biological father, thereby raising new issues for family regulation. Current controversies in 
France about granting stepfathers a legal status testify to the tensions surrounding the conceptualization of parenthood and parenting. ${ }^{4}$

\section{Contrasting Patterns of Lone Parenthood in European Societies}

Changes in the profiles of lone parents reflect a move from a lone parenthood regime in which one of the parents is missing to a regime in which high proportions of children have two parents who live separately and who may or may not have been married or living together as partners. This change over time has not been uniform in all countries, depending on attitudes and policies towards marriage and divorce, as well as on the representations of what the family is or should be. So the three main life trajectories leading to lone parenthood are not distributed in the same way in all European countries. Comparative data provided by the EU Statistics on Income and Living conditions (Chzen and Bradshaw 2012) and a comparative study carried out for the European Commission by the Brodolini Foundation (Trifiletti 2007) show that the vast majority of lone parents are divorced, separated or single parents, whereas widowed lone parents have become a minority in all EU countries, in spite of some cross-national variations. In 2009, proportions of widowed lone parents were higher in former socialist countries (24\% in Romania, 12-14\% in Poland, Lithuania, Bulgaria and Hungary), as well as in Greece (15\%), Cyprus (15\%), Italy (11\%) and Spain (11\%); in other countries proportions of widowed parents were as low as $2-3 \%$ in Sweden, UK, Ireland, Denmark, Finland and Iceland, and below $11 \%$ in the other countries.

The other two trajectories into lone parenthood also show some striking crossnational variations. Three patterns may be highlighted. A first pattern linked to high and almost equal proportions of both never-partnered and divorced/separated lone parents. In the UK, Ireland, Sweden, Norway, Iceland, and Slovenia at least half of all lone parents report their marital status as single, thereby highlighting not only the well-known impact of early pregnancies, in particular in the UK and Ireland, but also a possibly growing trajectory linked to voluntary independent motherhood or deriving from "living apart" couples. Sweden stands out among Scandinavian countries due to its relatively high age of lone parenthood: only $18 \%$ of lone parents are under age 35 , compared to $38 \%$ in the UK. Routes to lone parenthood differ in these two countries, especially with respect to the incidence of early pregnancies, which are not as common in Sweden. Lone parenthood is widespread in Ireland and the UK, due in particular to young un-partnered mothers. The high proportion of early pregnancies in these two countries is often associated with lone motherhood, though

\footnotetext{
${ }^{4}$ The introduction of a bill on 'parental responsibility and child's interest' was postponed because of strong opposition. The draft discussed in Parliament in 2014 defined the legal status of stepparents, thereby acknowledging the value of the relationship between children and step-parents. Opponents advocated in favor of a sole type of parenthood based on biological links rather than on everyday care relationships.
} 
not always. As a consequence, the average age of lone mothers is relatively low: $26 \%$ are under 30 in the UK compared to $12 \%$ of mothers living with a partner. More often too, they live in social housing or private rented accommodation, and their income is low (Finn 2011).

A second contrasting pattern is associated with a relatively low proportion (around one quarter or below) of single lone parents, mainly in new accession countries and some southern European countries (e.g. Romania, Hungary, Slovakia, Greece, Cyprus, Italy) and higher proportions of divorced (rather than separated) lone parents; as mentioned above, this pattern emerges in social contexts where marriage is still more widespread than cohabitation.

Finally, a third pattern reveals average proportions (around one third or slightly above) of single lone parents and varying proportions of both separated and divorced lone parents. In continental central European countries this would seem to represent the mainstream pattern, with trajectories linked to separation and divorce representing the predominant trend, and single un-partnered mothers a persistent, rather than a declining, minority trend. Given that in these countries early pregnancies are rarer than in the UK and Ireland, the un-partnered pathway into lone parenthood may indicate a new pluralization of single motherhood and fatherhood, including both voluntary and involuntary transitions to parenthood.

As mentioned above, these patterns have to be examined in the context of other crucial variables such as living arrangements, gender, age and re-partnering. There is a striking divide between the old and new accession states in the share of multiunit households as opposed to living on their own. In some countries lone parents do not live alone with their children but with grandparents or in multi-unit households: in many former socialist and some southern European countries this involves the majority of lone parents (over half of all lone parents in Romania, Bulgaria, Hungary, Poland, Latvia, Slovakia, Slovenia, Greece, and Spain), pointing to vulnerable living conditions, difficult or late access to residential autonomy, and longstanding practices of multigenerational co-residence. National data in some countries show that it is more likely to find single, young and low educated lone parents, rather than divorced lone parents (usually older and better employed/educated), in this situation. By contrast, the share of lone parents living in multi-unit households in most EU countries is much lower (less than one third) but still represents a relevant trend that must be taken into account.

Within these broad patterns of lone parenthood combining types of trajectories into lone parenthood and living arrangements, lone-mother families continue to predominate, with estimates from the Luxembourg Income study showing that only $11.7 \%$ of one parent families are headed by fathers, but with significant national differences. Proportions are as high as 19\% in Sweden or Norway or as low as 8\% in the UK or Spain or even 5\% in Germany. A new profile of lone-father families may thus be gathering strength in some national contexts, in particular those with policies and practices more focused on gender equality in parenting, in response to involved fatherhood and more equal or shared gender roles in caring for young children. On average, lone fathers tend to be older than lone mothers. 
Behind these contrasted patterns are not only changing norms and practices related to marriage and parenthood, but also increasingly complex forms of family formation and reconstitution. To develop and explore these patterns, a life course perspective allowing to capture lone parent trajectories and meanings over time and across countries would greatly enhance our understanding of the current plurality of lone parenthood. For the moment, we can only rely on national approaches to this issue. National datasets reveal that lone parenthood is a temporary situation for many lone parents. Lone parenthood due to the death of a parent is often more temporary than for other trajectories to lone parenthood, with most widowed persons having repartnered after 4 or 5 years; however, this transition out of widowed lone parenthood seems to be slower and more difficult in Central and Southern European countries, probably due to the fact that older children leave home late. Separated parents also tend to repartner more rapidly than divorced lone parents, while neverpartnered lone parents, especially those with low educational levels or with several children, are those that tend to repartner less or less rapidly. However, cross-national comparisons related to these pathways are still to be explored.

In sum, the existing comparative data reveal a plurality of lone parent trajectories and families across European societies. They allow us to (very broadly) identify some major cross-national patterns: a stronger focus on widowed and divorced (rather than separated) lone parents who also live more often in multiunit households in former socialist and southern European countries; a pattern strongly linked to early pregnancy within single lone parenthood as well as divorce and separation in the UK and Ireland; a pattern linked to high proportions of both single and separated/divorced lone parent trajectories and a strong increase in lone fathers in some of the gender-equality-oriented Nordic countries; a mainstream pattern in other central European countries such as France, Germany or the Netherlands, with somewhat lower proportions of single un-partnered lone parents and lone-father families, and a major focus on separated and divorced lone parents. However, the datasets also highlight huge gaps and insufficiencies in data analysis. We lack not only longitudinal datasets and in-depth national and cross-national studies of lone parent life trajectories but also simple cross-tabulations taking into account the characteristics of lone parents or multilevel analyses testing for the influence of different biographical and structural variables across different national contexts.

\section{Old and New Challenges for Family and Social Policy}

Lone parenthood challenges social policy, firstly by calling into question established parental norms, and secondly by exposing lone-parent families to the risk of poverty and social exclusion. Governments seek to develop policy measures in response to the issues raised by lone parenthood, and researchers are called upon to review their conceptual approach to lone parenting by taking account of changing patterns over the life course, the socio-demographic transformation of European societies, and their greater cultural diversity. 


\section{Changing Norms: From Stigmatization for Moral Reasons to Stigmatization of Poverty and Welfare State Dependency}

Changing attitudes towards different family forms have accompanied changes in living arrangements. Unmarried cohabitation and divorce and the associated diversity in family trajectories are more readily accepted in society today, as testified by respondents in the French gender and generations survey (Mainguené 2011). Half of the respondents agreed that women can have and raise children alone if they wish, whereas respondents stress the importance of having two parents to bring up children.

The diversity of living arrangements is illustrated by the following statistics for France: in 2011, $72 \%$ of cohabiting couples were married, $22 \%$ were not married, $4 \%$ were in a civil partnership (Pacs), ${ }^{5}$ and $2 \%$ did not answer the question. Among the $0.5 \%$ recorded as living with a same-sex partner, a share of $16 \%$ was not daily living with the partner. Of these same-sex cohabitants, $60 \%$ were male and $40 \%$ female couples; while $43 \%$ were in a civil partnership, the rest were cohabiting (Buisson and Lapinte 2013). These figures reflect the complexity of living arrangements and the increasing disconnection between living under the same roof (co-residence) and being partnered or cohabiting (subjective perception of partnership). Figures also show that marriage is no longer a mandatory prelude to living as a couple and forming a family. Together with the diversification of family forms, the increase in separation has contributed to the trivialization of lone parenthood, which is no longer stigmatized for moral reasons: single mothers are no longer viewed as acting immorally and producing illegitimate children; and sexual relations outside wedlock are no longer viewed as reprehensible behaviour. Instead, stigmatization may be for welfare reasons: lone mothers may be stigmatized for their poverty and dependency on the welfare state, being seen as 'scroungers' always in need of support (Thane and Evans 2012). Discrimination may also emerge in other situations. For example, single women are not entitled to state support for assisted reproduction in all European countries, being accessible only for the heterosexual parental couple.

Attitudes have changed not only towards cohabitation, marriage and divorce, but also towards gender roles and parenthood. Fathers are likely to spend more time looking after their children, especially in the younger generations of fathers: $42 \%$ of the respondents in the Family and Housing survey carried out by INSEE said that it is neither better, nor worse, if a child stays with the mother after separation of the

\footnotetext{
${ }^{5}$ The Pacte civil de solidarité-PACS is one of two forms of union under the French Law. It is a partnership agreement between two same-sex or heterosexual adults. Since the creation of the Pacs in 1999 more than one million people have signed a partnership agreement. In 2011, 175,000 Pacs were contracted, compared to 250,000 marriages. Marriage was extended to same-sex couples in 2013, thereby opening the right for same-sex couples to adopt a child. By opening marriage to all couples, France was the ninth country in Europe to allow same-sex couples to marry, following the Netherlands, Belgium, Spain, Norway, Sweden, Portugal, Iceland and Denmark. In 2013, 7000 same-sex weddings were celebrated in France; in nine out of ten cases, the wedding involved two men (Bellamy and Beaumel 2014).
} 
parents' while $30 \%$ assess that it is better for the child to live with the mother, and $28 \%$ disagree with this statement. Young respondents disagreed more often than older respondents with the systematic allocation of custody to the mother: $22 \%$ of those aged under 25 disagreed, compared to $45 \%$ of those over 75 (Buisson and Lapinte 2013).

\section{Policy Responses to Changing Models of Parenthood}

Divorce or separation of cohabiting parents challenge firstly the children's legal right to their two parents irrespective of their living arrangements, and secondly arrangements for ensuring that parental responsibilities including maintenance, education and childcare, are shared equitably between parents. Lone parenthood is seen as a risk for society, thus requiring a policy response: lone parenthood has become a major concern for governments and public policy because it is associated with the risk of poverty and social exclusion.

Despite the introduction of no-fault divorce in most European countries, conflicts often arise between parents about alimony, custody and the sharing of parental responsibilities. Conflicts arise also about the compensation for loss of income by a spouse who has devoted most of her life to looking after her family. In several countries, spousal maintenance has been progressively withdrawn as women's participation in the labour market has increased. Safeguarding the living standards of the spouse nevertheless remains a controversial issue for the courts. In France, the legislator has attempted to solve these conflicts by strengthening the role of family mediation, which is financially supported by the Family Allowances Fund. Divorce by mutual consent is now actively promoted and applies in more than half of all divorces in France. In $85 \%$ of cases, the court endorses the agreement reached by parents, while in $10 \%$ of cases it falls to the judge to make a decision about the child's residence, the level of alimony and custody.

The child's place of residence is another controversial issue. In all countries, most children live with their mother. In France, the child's main residence is assigned to the mother in $77 \%$ of divorce cases and in $84 \%$ of separations of nonmarried parents. Only $14 \%$ of children under 25 live most of the time with a lone father, usually older children: $18 \%$ of the 17-24 age group, compared to $10 \%$ of children under 6 and 3\% of children under 2 (Chaussebourg and Baux 2007). Although custody is predominantly entrusted to the mother, shared-residence doubled between 2003 and 2012, from 12\% to 21\%. Shared residence is now determined in $30 \%$ of divorces by mutual consent. According to data published by the Department of Justice, altogether $17 \%$ of children with separated and divorced parents live alternately with fathers and mothers (Carrasco and Dufour 2015). The choice of residence depends however on the age of the child: children below six live more often with their mother, whereas grown up children, especially boys, tend to move to the father's residence. A consequence of growing shared residence is the decrease in the number of alimonies. 
Encouraging fathers to share the responsibility for children more equally with mothers after separation has become a policy objective in several countries, although experts in child development and family associations do not always agree on the merits of such a decision, as shown by parliamentary debates in France over the new family law in 2014. On the one hand, proponents of the law, including associations of divorced and separated fathers, advocated alternating residence in the name of gender equality between parents; on the other, opponents argued for a traditional view of the family, whereby children should be cared for by their mother in the best interests of the child. Recent studies on fathers 'involvement in children's education and care identified three profiles of separate/divorced fathers, thereby illustrating changing contemporary fatherhood profiles. Changes have to do with policy discourse, public debates and practices as well. After having been 'absent' until the 1990 s, fathers have become 'occasional' or 'intermittent' in the 2000s, then 'alternating' with mothers in shared/joint custody (Martial 2013a). The tempo of change differs across countries, depending on the policy and legal context, on the father's voice, and also on change in divorce regulations. The shared residence that has been legally encouraged in France for the last 15 years is conceived as a means of sharing parenting ("co-parentalité"). According to the French law, co-parenting requires a shared residence for children to spend the same amount of time with the two parents while having close relationships with the two parents. A comparison of shared residence arrangements in various European countries highlights the difficulties encountered in measuring these situations, in particular because there is no consensus on the terms used to describe these arrangements (Masardo 2014). The study also shows that the concept of shared residence in most European countries is not always effective in practice since the latter are shaped and limited by social norms regarding parenting and gender roles. Shared residence is however more common for children with high educated parents than for children whose parents have low educational attainment or are unemployed. The debate on shared residence is not closed; it includes issues relating to parenting, the respective roles of fathers and mothers, and what would be the best for the children. The lack of consensus within and between countries reflects contrasting views regarding the changing values underpinning the male breadwinner family model and, consequently, parental responsibilities and roles. Finally, although shared residence for children of separated parents has gradually increased, it is still more common in Nordic countries, especially in Sweden, than in South European countries where intergenerational solidarity is highly valued and where family members, particularly grandmothers, provide support for their sons as lone fathers. Qualitative studies of lone fatherhood suggest that this intergenerational arrangement is also common in France (Martial 2013b).

Decisions about child maintenance payments are made in $86 \%$ of divorce settlements in France, the exceptions being for parents who alternate custody. The level of payments is generally higher for fathers than for mothers, reflecting the gender income gap. A major concern for family policy is to support lone parents for whom maintenance is not paid or not paid regularly. Although the exact proportion of parents who do not pay alimony is not well reported, this situation is known to have a negative impact on living conditions for children. In some countries, temporary 
financial support is provided to lone parents while social services undertake proceedings to collect unpaid maintenance.

Another challenge for policy makers is how to ensure that parental contact is maintained after divorce. According to the French version of the Gender and Generations Survey carried out in 2005, approximately $15 \%$ of children living with a lone father had 'very little or no contact' with the mother during the year, compared to $40 \%$ of children living with a lone mother who rarely or never had contact with the father. However, $42 \%$ of children living mainly with their mother meet their father at least once a week (Chardon et al. 2008). So, children living with fathers have it easier to keep contacts with the mother than the reverse. On the one hand, there may be social norms on parenthood encouraging differential contacts by gender, while on the other hand, those fathers who have full custody are particularly selected as being 'good fathers' highly involved in the well-being of their children.

Another challenge for public policy is how to redefine the meaning of 'parenthood', especially when children are living in reconstituted or blended families. The increasing development of divorce and separation in family trajectories, together with repartnering and childbearing after separation has resulted in a complexification of family forms, as noted above, ${ }^{6}$ in which biological parents may not be the 'social' or main carer parent. The status of step-parents has become difficult to determine, since social practices change more rapidly than legislation (Lapinte 2013). In the 1990s, the French sociologist Irène Théry suggested using the term 'démariage' to denote a social phenomenon that was spreading rapidly at the end of the twentieth century (Théry 1993). The term refers less to the decline in marriage rates or to the depreciation of the value attributed to marriage than to the role of marriage as an institution in Western parenthood systems and, consequently, in the gendered organization of social life.

From being a widespread social norm until the 1970s, marriage has become a matter of personal choice. Rather than disqualifying marriage, the term 'démariage' relativizes it as being the starting point for establishing a home and a family. Today, both spousal and parental bonds are no longer regulated within the framework provided by the marriage institution. Since the 1972 French law establishing equality between children irrespective of filiation (married or non-married mothers), the sacred aura of marriage progressively vanished being replaced by parenthood norms that differ from the normative context previously associated with the traditional family based on a marital union and endorsed by law in the Napoleonic Legal Code. At the same time, the term 'démariage' raises another policy issue, namely how to handle diversity in the biographical trajectories linking children to parents. However, despite changing behaviour and value systems, marriage is still seen as the foundation of the 'true family' (Théry 2013), bringing together the three components of filiation - biological, social/educative and legal - in which both parents act as creator, carer and protector of the child in a symbolic parenthood system. This model

\footnotetext{
${ }^{6}$ Among the $9 \%$ of children living in a reconstituted family, half live with their mother and a stepfather whereas $15 \%$ live with their father and a step-mother. Slightly more than one third alternate between their two parents who both have children from the new union.
} 
of family life, which served as a reference for both individual behaviour and policy, is no longer relevant today because of the growing number of blended families, adoption and assisted reproduction with a donor (Théry 2013). A multi-parenthood model is progressively replacing the "patrimonial" model of filiation. As a consequence, if parenthood is becoming multidimensional and diverse in its definition and practices, then it needs to be the central focus of policies.

\section{Challenging Social Policy: Lone Parenthood as a Social Risk}

In general, lone parents are more likely to be at risk of poverty and social exclusion than two-parent families, whether in access to labour markets or to an adequate income.

Whereas lone parents are heterogeneous with respect to their family trajectories, demographic characteristics, educational levels and maintenance arrangements, they share some common features. First, they generally have an income per consumption unit lower than one-earner couples (25\% lower in France) and dual-earner couples with children (54\%). Their poverty rate before social transfers is higher than for other households: 57\% compared to 20\% for French households in general, and $22 \%$ for couples with children. Social support helps to offset poverty rates: in France, the poverty rate ${ }^{7}$ for lone parents falls to $32 \%$ after social transfers, compared to $14 \%$ for total population and $13 \%$ for couples with children. Nevertheless, one lone-parent household in five depends on the minimum income (Burricand et al. 2012).

The high risk of poverty among lone parents is addressed by social policy in all European countries, with variations in incentives to participate in the labour force (Eydoux and Letablier 2009). Although some countries support lone mothers by helping with childcare, as in Ireland, others such as Sweden, and to some extent France, encourage lone mothers to return to work. In general, the conflict between working and mothering is greater for lone mothers, often due to difficulties in access to adequate and affordable childcare provision. A number of reasons concur to exclude lone mothers from full participation in the labour market, therefore making them dependent on welfare support. Only half of lone mothers have a full-time job in France, although they are the main provider of family income. The low earning power of many lone parents explains the deterioration in their living conditions. In addition, lone parents are more likely to live in rented accommodation than other households, and are less likely to own a car than other couples with children.

A major challenge for social policy is to reduce the poverty risk of lone parents by providing social transfers and/or reducing taxes. Both measures are used in France. The lone parents benefit was introduced in the mid-1970s to support lone parents during transitions. The benefit was temporary and means-tested. In contrast with the British lone parent benefit, which was provided until the child reached the

${ }^{7}$ The poverty threshold is defined relative to $60 \%$ of the median income. 
age of 16 (Finn 2011), the French allowance was expected to cease when the child turned three and began attending pre-school, thereby allowing the mother to return to work. Lone-parent benefit was merged with minimum income in 2011, which means that eligibility is no longer linked to lone parenthood but to poverty. As a consequence, half of minimum income recipients are lone parents, and only $16 \%$ of these lone parents have a job.

\section{The Relative Failure of Activation Policies}

In line with the recommendations of international organizations such as the OECD, UNICEF and the European Union, policies aimed at reducing lone parents' poverty risk combine two sets of measures: providing social assistance and encouraging to work. Activation policies have targeted lone parents, notably lone mothers, with the aim of reducing their dependency on the state. Welfare-to-work policies, or workfare policies, have been developed in the 1990s onwards in order to raise the employment rates of lone mothers, thereby increasing their economic security (Letablier et al. 2011).

Lone parents' participation in the labour force varies between and within countries, depending on family trajectories, level of education and gender. In France, $23 \%$ of lone mothers have a high level of education, compared to $30 \%$ for partnered mothers, but separated or divorced lone mothers have a level of education similar to partnered mothers. Consequently, their employment rate is generally higher than for lone mothers who never lived in couple. Never-partnered lone mothers are also younger and have a lower education level. They include an increasing number of immigrant women. Overall, the activity rates of lone mothers are higher than for partnered mothers, but they are more often unemployed. When employed, they work part time less often than partnered mothers (26\% compared to 34\%). The proportion is lower in professional occupations (16\%) but much higher for low-qualified lone mothers (39\%) who are likely to be working part time because they have been unable to find a full-time job. Part-time work is generally associated with low wages, irregular income and poor quality jobs, for example in health and care services, especially in care for older people and housework. Lone fathers seem to fare better since $75 \%$ have a full-time job, though they are more likely to be unemployed than fathers living in couple.

Comparison of lone mothers' employment in Germany, France, the UK and Sweden shows that the proportion of economically inactive lone parents has declined almost everywhere, but lone parents are more likely to be unemployed than partnered mothers, the largest gap being in the UK and the smallest in Germany (Jaehrling et al. 2015). The success of welfare-to-work policy depends largely on the effectiveness of policy implementation, context (familialist or maternalist states) and on the types of jobs available. Part-time work reflects country-specific labour market patterns: in Germany and the UK, despite the high incidence of part-time work in general and of short part-time in particular, lone parents are less often in 
mini-jobs than women in couples; in France and Sweden, where part-time work is less common, part-time rates are also lower for lone mothers, particularly in Sweden. The specificity of France lies in the gap between high and low-qualified lone mothers and the incidence of part-time work for low qualified women when they would prefer to have full-time jobs (Eydoux and Letablier 2009). Qualitative research highlights the effect of low qualification on lone mothers' poverty risks also the effect of working conditions of the jobs they are offered: jobs are often part-time, but they are also often temporary (short-term contracts) with irregular working hours that are difficult to combine with childcare needs (Avenel 2008). Poor lone mothers who do gain access to a job are often found to be those who can rely on some form of family support, whereas those who remain unemployed are often immigrant women or women with no family or social support.

In Sweden, the labour force participation rate of lone mothers has not differed from that of mothers living in couples since the 1970s, Full-time participation is high whatever the mother's living arrangements. Mothers in couples are, however, more likely to work part-time than lone mothers (Hobson et al. 2011). Finally, the success of activation policies depends both on measures to make work pay and on services provided to lone mothers to reduce the work-family conflict.

In Italy, as in other Southern European countries where social benefits are limited, lone mothers have no other choice than to be economically active. The employment rate of lone mothers, as also the unemployment rate, is notably higher than for partnered mothers. Less than $20 \%$ of lone mothers do not participate in the labour force compared to $47 \%$ for married mothers. Similarly, divorced or separated mothers are more often in the labour force than partnered mothers. The relatively high employment rate of lone mothers in Italy goes together with the high level of education of divorced or separated mothers. A similar profile for lone mothers is found in Spain.

\section{Conclusion}

A key aim in this chapter was to explore the changing patterns of lone parenthood in European societies and to reflect on the ensuing challenges for research and policy.

A first issue was to understand how lone parenthood is defined and to what extent existing definitions provide precise, coherent and overarching concepts. Analysis reveals that the most common definitions of lone parenthood tend to oversimplify the diversity and complexity of family life as a lone parent. In some cases, the definition is too narrow, assuming for example that a single lone mother is always unpartnered and un-supported. In other cases, it is too wide, incorporating into the same concept lone parents living on their own and those living in a complex family household. In other cases, still, the definition fails to take into account an in-depth analysis of new forms of co-parenting, such as the situation of separated/divorced parents who share parental time and responsibilities with a non-residential parent. 
More research seems to be needed: on the complex and diverse pathways into and out of lone parenthood; on the personal and family configurations of lone parents, in order to capture their support networks and interdependencies; on the diverse meanings of lone parenting, based on the subjective choices and lived experiences of both mothers and fathers; on the impact of new fathering practices on the changing patterns of lone parenthood; on labour market segregation and how it influences gender inequalities in lone parenting. Research would therefore benefit from studies combining a variety of approaches: a qualitative as well as a quantitative approach, in order to capture the new meanings and negotiations of lone parenting from the perspective of parents themselves; a family network approach together with a demographic approach, in order to move beyond the focus on the nuclear family and on household structure at a specific point in time; a life course perspective as well as a gender perspective, in order to highlight both the different pathways and the gendered disadvantages of lone parenthood.

A second issue was to understand old and new challenges for social and family policies in this field. Poverty and social exclusion continue to be a major challenge, since there are lone parents who suffer from a combination of several types of disadvantages: gender (mothers), younger children, lower educational attainment levels, immigrant background, unstable or part-time jobs in the labour market. Analysis also reveals a new trend in policy-making: a move away from a family policy perspective focusing on the vulnerability of lone parent families in general and a shift towards a social policy perspective seeking to provide social benefits for disadvantaged persons and families, with little concern for specific family type. The consequences and effects of such a trend (e.g. in France) have yet to be analyzed. They are likely however to increase stigmatization of young low educated lone mothers, those who find it more difficult, in all European countries, to move from welfare to work and to be residentially and economically independent in order to bring up a dependent child on their own. Raising awareness and debate on this issue and how it may reproduce stigmatization is an important challenge for social policy research.

Policy responses to changing patterns of parenthood are a last major challenge. The higher the number of lone parents, the higher their diversity in European societies. Lone parenthood is nowadays one among many contemporary family forms. Whereas these living arrangements have increased markedly over the past 50 years, albeit to varying degrees across countries, their social acceptability has also changed considerably. For children, the complexity of living arrangements means that, instead of being assigned throughout their childhood to a lone parent, they often have several parents each performing different roles. Sociologists and policy makers have attempted to redefine lone parenthood without providing a satisfactory answer so far as to how to take proper account of the many changes in living arrangements from a life-course perspective.

Acknowledgements This paper benefited from the support of the Swiss National Centre of Competence in Research LIVES - Overcoming Vulnerability: Life Course Perspectives, which is financed by the Swiss National Science Foundation (Grant number: 51NF40-160590). 


\section{References}

Avenel, C. (2008). "Les enjeux de l'évaluation des expérimentations du revenu de solidarité active ». Informations sociales $\mathrm{n}^{\circ} 150$ (6) : 80-96.

Beauchemin, C., Borrel, C., \& Regnard, C. (2013). «Les immigrés en France : en majorité des femmes ». Population \& sociétés $\mathrm{n}^{\circ} 502$.

Bellamy, V., \& Beaumel, C. (2014). « Bilan démographique 2013. Trois mariages pour deux pacs ». Insee Première $\mathrm{n}^{\circ} 1482$.

Bonnet, C., Garbinti, B., \& Solaz, A. (2015). « Les conditions de vie des enfants après le divorce ». Insee Première $n^{\circ} 1536$.

Buisson, G., \& Lapinte, A. (2013). « Le couple dans tous ses états : non cohabitation, conjoints de même sexe, pacs... ». Insee Première $\mathrm{n}^{\circ} 1435$.

Buisson, G., Costemalle, V., \& Daguet, F. (2015). « Depuis combien de temps est-on parent de famille monoparentale ?». Insee Première $n^{\circ} 1539$.

Burricand, C., Houdre, C., \& Seguin, E. (2012). « Les niveaux de vie en 2010 ». Insee Première $\mathrm{n}^{\circ} 1412$.

Carrasco, V., \& Dufour C. (2015). «Les décisions des juges concernant les enfants de parents séparés ont fortement évolué dans les années $2000 »$. Infostat Justice n ${ }^{\circ} 132$ : 1-6.

Chapple, S. (2009). « Child well-being and sole-parent family structure in the OECD : an analysis ». OECD Social, Employment and Migration Working Papers. ${ }^{\circ}$ 82, OECD Publishing.

Chardon, O., Daguet, F., \& Vivas, E. (2008). « Les familles monoparentales. Des difficultés à travailler et à se loger ». Insee Première $\mathrm{n}^{\circ} 1195$.

Chaussebourg, L., \& Baux, D. (2007). L'exercice de l'autorité parentale après le divorce ou la séparation de parents non mariés, Note du Ministère de la justice.

Chzhen, Y., \& Bradshaw, J. (2012). Lone parents, poverty and policy in the European Union. Journal of European Social Policy, 22(5), 487-506.

Duncan, S., \& Edwards, R. (1997). Introduction: A contextual approach to single mothers and paid work. In S. Duncan \& R. Edwards (Eds.), Single mothers in an international context: Mothers or workers? London: University College.

Eydoux, A., \& Letablier, M.-T. (2009). « Familles monoparentales et pauvreté en Europe : quelles réponses politiques? », Politiques sociales et familiales $\mathrm{n}^{\circ} 98,21-36$.

Finn, D. (2011). Country report on labour market participation and socio-economic situation of lone parents in the UK. Report commissioned by Institut Arbeit und Qualifikation (IAQ), university of Duisburg-Essen. http://www.iaq.uni-due.de/aktuell/veroeff/2011/alleinerziehende01.pdf

HCF. (2010). «Ruptures et discontinuités de la vie familiale. Les séparations et divorces des parents », La lettre du Haut Conseil à la Famille $\mathrm{n}^{\circ} 05$.

Hobson, B., Carlsson, L., Fahlen, S., \& Anderberg, E. (2011). Country report on labour market participation and socio-economic situation of lone parents in Sweden. Report commissioned by Institut Arbeit und Qualifikation (IAQ), university of Duisburg-Essen. http://www.iaq.unidue.de/aktuell/veroeff/2011/alleinerziehende02.pdf

Insee. (2012). Immigrés et descendants d'immigrés en France. Edition 2012. Paris.

Jaehrling, K., Kalina, T., \& Mesaros, L. (2015). A paradox of activation strategies: Why increasing labour market participation among single mothers failed to bring down poverty rates? Social Politics 2015, 22(1), 86-110.

Lapinte, A. (2013). «Un enfant sur dix vit dans une famille recomposée ». Insee Première $\mathrm{n}^{\circ} 1470$.

Lefaucheur, N. (1986). Les familles monoparentales: Des chiffres et des mots pour le dire. Formes nouvelles ou mots nouveaux? In Aidelf-Association internationale des démographes de langue française (dir.), Les familles d'aujourd'hui (pp. 173-181). Paris: PUF.

Lefaucheur, N., \& Brown, E. (2011). « Relations conjugales et configurations parentales à la Martinique ». Politiques sociales et familiales $\mathrm{n}^{\circ} 106: 9-23$. 
Lefèvre, C., \& Filhon, A. (2005). Histoires de familles, histoires familiales. Les résultats de l'enquête Famille de 1999. Cahiers de l'Institut National d'études démographiques. Paris: Presses Universitaires de France.

Leridon, H., \& Villeneuve-Gokalp, C. (1994). Constances et inconstances de la famille : Biographies familiales des couples et des enfants. Paris: Ined.

Leridon, H., Zucker, E., \& Casenave, M. (1970). Fécondité et famille en Martinique : Faits, attitudes et opinions. Paris: Ined-PUF.

Letablier, M.-T. (2011a). La monoparentalité aujourd'hui : Continuités et changements. In E. Ruspini (dir.) (Ed.), Monoparentalité, homoparentalité, transparentalité en France et en Italie. Paris : L'Harmattan (Logiques sociales).

Letablier, M.-T. (2011b). Country report on labour market participation and socio-economic situation of lone parents in France. Report commissioned by Institut Arbeit und Qualifikation (IAQ), Universität Duisburg-Essen. http://www.iaq.uni-due.de/aktuell/veroeff/2011/alleinerziehende03.pdf

Letablier, M.-T., Eydoux, A., \& Betzelt, S. (2011). Social citizenship and activation in Europe: A gendered perspective. In S. Betzelt \& S. Bothfeld (Eds.), Activation and labour market reforms in Europe. Challenges to social citizenship (Work and welfare in Europe series, pp. 79-100), Houndmills/New York: Palgrave Macmillan.

Mainguené, A. (2011). « Couple, famille, parentalité, travail des femmes ». Insee Première ${ }^{\circ}$ 1339.

Mainguené, A. (2013). «Les familles monoparentales immigrées cumulent les difficultés ». Info migrations $\mathrm{n}^{\circ} 52$. www.immigration.interieur.gouv.fr.

Martial, A. (2013a). « Des pères 'absents' aux pères 'quotidiens': représentations et discours sur la paternité dans l'après divorce ». Informations sociales $n^{\circ} 176,30-44$.

Martial, A. (2013b). « Une paternité ré-inventée ? Le vécu familial des pères isolés ». Informations sociales $\mathrm{n}^{\circ} 176: 62-70$.

Martial, A. (2013c). « Paternité, maternité, et coparentalité à l'aune de nouveaux contextes : la résidence au père et la résidence alternée $»$. Dialogue $\mathrm{n}^{\circ} 201: 57-68$.

Masardo, A. (2014). Shared residence: Changing perceptions of what is appropriate for the postseparation care of children. Paper for the international conference, Barcelona University.

Mulot, S. (2013). « La matrifocalité caribéenne n'est pas un mirage créole ». L'Homme n 207208 (3) : 159-191.

OECD. (2011). Doing better for families. Paris: OECD Publishing.

Thane, P., \& Evans, T. (2012). Sinners? Scroungers? Saints? Unmarried motherhood in twentiethcentury England. Oxford: Oxford University Press.

Théry, I. (1993). Le démariage. Justice et vie privée. Paris: Odile Jacob.

Théry, I. (2013). Maternité et paternité hors mariage. In H. Fulchiron \& J. Sosson (Eds.), Parenté, filiation, origines. Le droit à l'engendrement à plusieurs. Paris: Editions Bruyland.

Toulemon, L., \& Pennec, S. (2010). Multi-residence in France and Australia: Why count them? What is at stake? Double counting and actual family situations. Demographic Research Journal, 23, 1-40. www.demographic-research.org/volumes/vol23/1/default.htm

Trifiletti, R. (2007). Study on poverty and social exclusion among lone-parent households. Fondazion Brodolini: Report for the European Commission. www.fondazionebrodolini.it.

Vanassche, S., Corijn, M., Matthijs, K., \& Swicegood, G. (2015). Repartnering and childbearing after divorce: Differences according to parental status and custodial arrangements. Population Research and Policy Review, 24(5), 761-784.

Wall, K., \& Gouveia, R. (2014). Changing meanings of family in personal relationships. Current Sociology, 62(3), 352-373.

Widmer, E. (2010). Family configurations. A structural approach to family diversity. Farham: Ashgate. 
Marie-Thérèse Letablier Senior Researcher Emeritus, Centre national de la recherche scientifique - CNRS - and Centre d'Economie de la Sorbonne - CES - Université Paris1 PanthéonSorbonne. Her main research interests are in family policies, family welfare, fertility, gender equality and work-life balance, in a European comparative perspective.

Karin Wall Research Professor at the Institute for Social Sciences at the University of Lisbon (ICS-UL). Her main areas of expertise are comparative social policy and sociology of families and gender. Her research interests include family policies, family forms and interactions, gender equality and work-family balance, lone parent and migrant families, family trajectories and the life course.

Open Access This chapter is licensed under the terms of the Creative Commons Attribution 4.0 International License (http://creativecommons.org/licenses/by/4.0/), which permits use, sharing, adaptation, distribution and reproduction in any medium or format, as long as you give appropriate credit to the original author(s) and the source, provide a link to the Creative Commons license and indicate if changes were made.

The images or other third party material in this chapter are included in the chapter's Creative Commons license, unless indicated otherwise in a credit line to the material. If material is not included in the chapter's Creative Commons license and your intended use is not permitted by statutory regulation or exceeds the permitted use, you will need to obtain permission directly from the copyright holder.

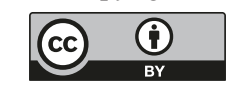

